\title{
Georg Simmel at the Lectern: The Lecture as Embodiment of Text
}

\author{
JANET STEWART
}

As Privatdozent and later, außerordentlicher Professor at the University of Berlin hoping to be appointed to a permanent position, Georg Simmel's task was to prove himself by attracting students to his courses. By all accounts, he was rather successful in this; the majority of the articles on Simmel contained in Buch des Dankes an Georg Simmel (Gassen and Landmann, 1958), a collection put together on the 100th anniversary of Simmel's birth, are written by his former students, many of whom focus on his talents as a lecturer. Simmel's correspondence with Heinrich Rickert, published in the same collection, also documents the increasing popularity of Simmel's lecture courses at the turn of the century. ${ }^{1}$ In a letter dated 27 January 1900, Simmel wrote: 'For my part, I have occasion to be satisfied with both work and my students, at least quantitatively speaking. I have around 315 students in my three courses' (Gassen and Landmann, 1958: 99). Moreover, Simmel did not only employ his talents as a speaker in the university sector, but extended his speaking activities in two main directions. First, as documented in the recollections of his son, Simmel often accepted invitations to speak in public, both in Berlin and in other cities throughout Europe: 'he [Simmel] greatly loved this activity of a "wandering priest". He found it exciting; on the return journey he sometimes already worked on his next lecture' (Hans Simmel, 1976: 258). ${ }^{2}$ Second, during the First World War, Simmel became known for his addresses to the German troops, and later related the tale of the soldiers who left his lecture on 'Goethe and Love'3 disappointed to have heard a philosophical discussion of love rather than a graphic description of Goethe's amorous conquests (Gassen and Landmann, 1958: 277).

Body E Society (C) 1999 SAGE Publications (London, Thousand Oaks and New Delhi), Vol. 5(4): 1-16 [1357-034X(199912)5:4;1-16;010787] 
Despite the obvious importance of the lecture form to Simmel, in the study of 'classical sociology', the original mode of presentation of his texts has been largely ignored. However, eye-witness reports of Simmel's lectures suggest the folly in such neglect. For example, Emil Ludwig has argued that the essential difference between Simmel's lectures and his written work lies in the relative accessibility of his lectures compared to the density of his texts. Indeed, he suggests that 'the difficulty of his [Simmel's] style of writing ... is resolved when the speaker resolves the sentence' (Gassen and Landmann, 1958: 154). While Ludwig focuses on the new perspective gained by the vocalization of the text, Paul Fechter describes the role that the physical presence of the body played in articulating Simmel's ideas:

\footnotetext{
... one watched while the figure on the lecture platform became the medium of an intellectual process, the passion of which was not only realized in words, but also in gestures, movements, actions. When Simmel wanted to reveal to his audience the heart of a thought, an idea, he didn't just formulate it: to an extent, he raised it visibly with his hand. His fingers stretched outwards and upwards and then closed again, his whole body turned under the force of his uplifted hand, in which the problem rested. (Gassen and Landmann, 1958: 160)
}

Curiosity having been aroused by these descriptions of Simmel's lecturing style, this article examines the dissemination of Simmel's sociological thought through the medium of the lecture, focusing on the production, reproduction and reception of sociological ideas, and foregrounding the physical presence of the body as an essential element of the lecture, distinguishing it from written forms. In so doing, it centres on the lectures which Simmel held at the University of Berlin, since these are the instances of Simmel lecturing which have been most extensively reported. In the context of exploring Simmel's lectures as a concrete example of the lecture as the embodiment of text, this article utilizes Simmel's writings on the body in order to provide a theoretical model for examining the lecture form. ${ }^{4}$ Thus, his lectures become both the site and the subject of the investigation, which is, first and foremost, concerned with the question of 'communicative bodies'.

The concept of the 'communicative body' is posited by Frank (1991) as part of his typology for a sociology of the body that also includes disciplined, mirroring and dominating bodies, and which focuses on orientations to corporeal action. By utilizing forms of action as his organizing principle, Frank opens new avenues of enquiry in the sociology of the body. However, in insisting that 'the essential quality of the communicative body is that it is a body in process of creating itself' which means that 'theory cannot describe such a body', Frank (1991: 79) brackets out the 'multi-systemic' nature of 'communicative events' (Loenhoff, 1997: 68). While Loenhoff highlights the manner in which the body is suppressed in many theories of communication, Frank's focus on purely corporeal forms such 
as performance art means that he foregoes the opportunity to explore fully the body of the lecturer as a communicative body in the context of a particular communicative event in which corporeal communication exists simultaneously with other forms of communication. Studies such as Goffmann (1969), Douglas (1970), and Benthall and Polhemus (1975) have used a variety of approaches to investigate the body as a 'medium of expression', echoing Fechter's description of the way in which, when lecturing, Simmel's body became 'the medium of an intellectual process' (Gassen and Landmann, 1958: 160). On a theoretical level, Bühler (1990) and Luhmann (1992) have been instrumental in creating models through which the complex interaction of different forms of communication in 'communicative events' can be explored (Loenhoff, 1997).

In the specific 'communicative event' represented by the lecture, a concern with the role of bodily expression has its roots in the study of rhetoric stretching back to Cicero's (1942) De oratore and Quintilian's (1920-22) Institutio oratoria, from whose analyses the term 'body language' stems (Kalverkämper, 1994: 132). And indeed, many works on rhetoric dating from the turn of the century, when Simmel was giving his lectures, follow in this tradition, discussing in prescriptive fashion the use of gesture in speech-making (for example, see Probst, 1916). ${ }^{5}$ However, not all studies of rhetoric from this period base themselves exclusively on classical antiquity. Geisler (1914), an instructor in rhetoric at the University of Halle, set himself the task of producing a textbook on rhetoric which would be firmly located in the socio-cultural landscape of Germany at the turn of the century. His work on the use of the body in the lecture situation moves beyond a classical study of gesture to focus on issues of health and morality, thereby suggesting connections with the bourgeois Lebensreform movement, which was concerned with the self-regulation of the body on moral and medicinal grounds (Barlösius, 1997).

Wunderlich (1898) undertook a rather more modern study than either Probst or Geisler, producing a theory of public speaking based on observation of Bismarck in action, examining, among other things, the effect of the personality, mood and gestures of the speaker. In producing a study based on observational data, Wunderlich anticipated the thrust of recent interdisciplinary work on 'nonverbal communication', which can be divided into three main areas of interest: first, as a cultural phenomenon; second, as a phenomenon involving observation of the body in a given communicative situation; and, third, as the focus of pedagogical studies (Kalverkämper, 1994: 138). In the specific case of Simmel's lectures, we are concerned with corporeal communication as a cultural phenomenon and also with the interpretation of data gained from observation in a given communicative situation. In other words, this article focuses on the interaction between physiognomic expression and physiognomic perception. 
'Perception' is a key term, both in the context of this article and in the wider context of the study of 'communicative bodies', as is neatly illustrated in the following statement: 'What communicative bodies are about is the capacity for recognition which is enhanced through the sharing of narratives which are fully embodied. What is shared is one body's sense of another's experience' (Frank, 1991: 89). Similarly, Loenhoff (1997: 71-5) writes of the centrality of perception and expression in experiencing and analysing communicative events. In the course of the argument, we shall see how Simmel's students perceived his lectures as the opportunity to share in his thought-processes. However, before turning to a detailed analysis of his lectures, it is necessary to develop the importance of 'perception', since Simmel's theoretical interest in physiognomy stems from the need to find new forms of perception in the wake of the increasing complexity of urban life at the turn of the century and the threat it posed for the subject (Asendorf, 1984: 127). Indeed, his theory of physiognomy is informed by the way in which 'he experienced the things he discussed with his own body' (Mattenklott, 1983: 145). He then sought to translate his lived experience (Erlebnis) of the metropolis into collective experience (Erfabrung) through the medium of the lecture, presenting an embodied narrative and thereby suggesting a correspondence between the lecturer and the Benjaminian figure of the Storyteller - 'the man who could let the wick of his life be consumed completely by the gentle flame of his story' (Benjamin, 1992: 107).

Embodying the narrative essentially allows the lecturer to play on physiognomic perception, attempting to overcome the threat to the subject posed by objective culture surging ahead; even if the self has been silenced, the embodied self can still communicate (Mattenklott, 1983: 140). Sociologists such as Giddens (1991) and Shilling (1993) have argued that in postmodern society, the 'project of the self . .. has been converted into the project of the body' (Turner, 1996: 20). However, the roots of this phenomenon can be observed at the turn of the century in the specific instance of physiognomic perception and expression, which was not only practised and theorized by Simmel, but also assumed an important place in the thought of others such as Ernst Mach (1987) and Friedrich Nietzsche (1969). Indeed, in Thus Spoke Zarathustra, Nietzsche presents his philosophy as an embodied narrative utilizing dance, acrobatics and other forms of movement. In other words, it is not only what Zarathustra says that is important, but also how he says it (Mattenklott, 1983: 143). In articulating and perceiving things which may not be expressible through language, in Nietzsche's philosophy, the body conceived 'as a relation of forces of the assimilated signs is an interpretative space' (Blondel, 1991: 238; emphasis in original).

Similarly, Simmel's theoretical concern with the body focuses on its status as 
an interpretative location. His physiognomy comprises both the study of set features of individuals and, more pertinently for this investigation, the study of gestures and movement styles, and he seeks to develop a theory which would explain immediate intersubjective understanding and also examine other dimensions of social and cultural experience (Moynahan, 1996: 44). Moreover, his theoretical concern with physiognomy is grounded in his conception of the body as the site of representation of thoughts and emotions, which, as he concludes in 'The Aesthetic Meaning of the Face', both reveals and conceals the Self (Simmel, 1995: 42). Indeed, in this and other essays, Simmel was instrumental in grounding a sociology of the emotions and intimacy (Nedelmann, 1983).

However, a warning note is sounded by Walter Benjamin (1982: 540) who, in his Arcades Project, seeks to distance himself from the phantasmagoria of the flâneur who believes that one can read the profession, background and character of a person from their face. He suggests that Simmel's 'Sociology of the Senses' has a certain affinity with this form of vulgar physiognomy, while simultaneously avoiding it (Benjamin, 1982: 545). Attempting to overcome the shortcomings of vulgar physiognomy, Benjamin's own work on corporeality is based on the idea of the body as a site of representation and framed by his interest in connections between language, perception and the body (Weigel, 1992: 58). In 'Problems of Socio-Linguistics', Benjamin (1972: 452-80) applies this field of interest to his analysis of contemporary linguistic theories, in which he rejects the simple, but popular schema that would describe the ontogenetic and phylogenetic development of language in terms of a move from mimesis to semiosis. Instead, emphasizing the simultaneity of the mimetic and the semiotic dimensions of language, he points to the work of theorists such as Heinz Werner and Rudolf Leonhard whose 'linguistic physiognomy ... crosses the threshold to the idea of the mimetic in language' (Benjamin, 1972: 478).

The rejection of a linear development from the mimetic to the semiotic also forms the central argument of Colin Sample's (1996) theory of the physiognomic aspect of aesthetic language which is grounded in the premise that the sensual and conceptual domains are intertwined in the Kantian 'aesthetic idea'. Sample distinguishes between the semiotic and the mimetic dimension of language in a manner similar to Benjamin, but defines the mimetic less ambiguously, as an instance in which 'the symbolic vehicle is itself somehow expressive of its meaning' (Sample, 1996: 114). ${ }^{6}$ He argues that aesthetic language in particular continues to make extensive use of the mimetic function: 'By seeking to present its meaning iconically instead of referring to it arbitrarily, aesthetic language presents "aesthetic ideas" that lend sensuous life to verbal language' (114-15). In exploring the physiognomic aspect of aesthetic language, Sample considers the interaction of physiognomic 
perception and physiognomic expression, which also forms the basis of Simmel's work on the body.

Sample (1996) suggests that in the context of mimetic communication, there are three main ways in which the body can present and perceive physiognomic aspects in a given communicative situation: vocalization, kinesis and facial expression. His article develops a framework through which we can explore the manner in which the physiognomic dimension of language connects it to the felt context of a sensual human being in the world. In other words, it is an ideal theoretical position from which to embark on a close analysis of Simmel's lectures as the embodiment of text. Examining vocalization, kinesis and facial expression in turn, the following section explores the aesthetics of Simmel's lectures, implicitly considering the way in which his lectures comprised a site in which 'aesthetic ideas' came into play. Indeed, just as performance art 'effaces the boundary between art and social theory' (Frank, 1991: 83), so, as we shall see, Simmel's lectures demonstrate the intersection of the aesthetic and scientific spheres through the interaction of the mimetic and semiotic dimensions of language.

The first category identified by Sample is 'vocalization', which is an aspect of corporeality neglected by Frank in his analysis of 'communicative bodies'. However, Frank is not alone in ignoring the effect of vocalization. In an article on 'Body Art' published the year before Simmel's 'Sociology of the Senses', Julius Bab (1906: 632) argues that contemporary theories of acting continually and erroneously conceive the body as a purely optical object, neglecting other important bodily functions which play a part in perception. Foremost in his list of 'other functions' is the human voice. Simmel makes a similar point in his 'Sociology of the Senses', in which he asserts that the correspondence between the speech sound and its meaning form a bridge through which one gains knowledge of the other. This correspondence leads 'us into the human subject as its mood and emotion and out to the object as knowledge of it' (Simmel, 1997: 111). Distinguishing between the human and the non-human object, he maintains that while sensory perception and recognition of the non-human object are two distinct processes, in the case of a person, emotional value and instinctive knowledge of sense impressions together form the foundation of a relationship to a person. In this analysis of sense impressions, based on the distinction between appearance and 'psychological interpretation', Simmel's thought demonstrates an unmistakable affinity with Ernst Mach's (1987: 50) 'principle of the complete parallelism of the psychic and the physical' which states that physical appearance and psychological interpretation are two different, but simultaneous, ways of observing the same process. However, while Mach's analysis of perception does not differentiate 
between the person and the non-human object, Simmel, a sociologist interested in social interaction, distinguishes sharply between them.

Turning to the specific situation of the lecture, we find that Simmel's analysis of the interaction between the sound of the voice and the content of the lecture is echoed by both Erving Goffman (1981) and Hans Georg Gadamer (1993). Goffman (1981: 167) maintains that the primary difference between the producer of a written text and the lecturer is that the lecturer is not only the author of a text, but also the 'animator' (the lecturer vocalizes the text) and the 'principal' (the lecturer appears to believe personally in what is being said). Similarly, Gadamer's (1993: 278) analysis focuses on a particular strength of the lecture which lies in the interaction between 'sense' and 'tone' that creates a sense of closeness by allowing the originator of an idea to voice that same idea. The existing accounts of Simmel's lecturing style make specific reference to his voice, and therefore, allow us to test this claim.

Analysis of these reports and impressions reveals that perception of the sound of the voice is, as Simmel argues, a subjective phenomenon. Both Ludwig and Richard Kroner describe Simmel's voice as 'laborious' in the first instance (Gassen and Landmann, 1958: 155, 228). Indeed, in a critical analysis of Simmel's lecturing style, Ludwig argues that Simmel's 'high sharp voice ... revealed acoustically how much Simmel lacked' (Gassen and Landmann, 1958: 155). Yet in contrast, Nikolas Spykman recalls Simmel's 'beautiful voice' and his 'elegant diction' (1958: 186). However, in a description which records not only the perception of Simmel's voice, but also its interaction with the content of Simmel's lectures, Kroner demonstrates the effect of the interpenetration of sound and content:

\footnotetext{
His voice, apparently slightly laborious, his language, and art of speaking were incomparable, completely original. His voice circled around the object so to speak, encircling it, holding, vibrating and then rising a little, intoning strangely and finally wrapping itself in the object, boring into it; it matched his form of thought exactly, this process of winding, slowly unwinding, turning and suddenly grasping, only to break off decidedly. Simmel 'simmeled' everything he concerned himself with. He shaped things so that they assumed and expressed his incomparable spirit, but at the same time reflected their own essence and truth. (Gassen and Landmann, 1958: 2287
}

Above all, as Simmel, Goffman and Gadamer recognize, how the lecturer presents his material is as important as what is said, since rhythm, tempo and intonation have been argued to structure behaviour and regulate communication (Loenhoff, 1997: 70). Indeed, in his account of Simmel's lectures, Kurt Gassen describes their complexity and difficulty, and suggests that the key to understanding them was to follow the tone of the lecture from word to word. He then focuses on the mimetic dimension of Simmel's use of vocalization, describing in detail its rhythm, tempo 
and musical intonation, and concluding that 'this kind of language, this way of speaking is that of the poet' (Gassen and Landmann, 1958: 301). It is hardly surprising that Simmel would have used aesthetic language to express his ideas, since he had an abiding interest in art and aesthetics, documented in his essays on Stefan George, Rembrandt, Rilke, Rodin, the Arts and Crafts Movement, Japanese art and others (Frisby, 1992: 89-90). And indeed, Kurt Singer maintains that the form of Simmel's lectures was influenced by his interest in Stefan George, whose style of delivery and dress Simmel adopted (Gassen and Landmann, 1958: 297-8). Moreover, Simmel favoured what Spykman has termed an 'artistic impressionistic' (1958: 186) approach to his subject matter. In the course of his examination into Simmel's 'sociological impressionism', Frisby (1992: 70) focuses on the aesthetics of Simmel's essays, arguing that the essay form possesses " "an aesthetic autonomy" that is both anti-positivist, anti-systematic and anti-academic'. The present investigation into Simmel's lectures suggests that similarly, the lecture form was also less a vehicle for the transmission of scientific knowledge than one for the expression of aesthetic ideas. ${ }^{8}$

In order to fully explore this hypothesis, it is necessary to develop the analysis of the physiognomic aspect of aesthetic language which, according to Sample (1996), is not confined to vocalization, but also includes kinesis and facial expression. Such a move is confirmed by reports of Simmel's lectures, since Bruckner, for example, maintains that in order to gain a full understanding of Simmel's work it was necessary not only to listen to him, but also to see him (Gassen and Landmann, 1958: 147). On a theoretical level, Simmel's 'Sociology of the Senses' upholds Bruckner's impression by exploring the essential difference between the ear and the eye in terms of perception:

\footnotetext{
... the most extreme sociological contrast between the eye and the ear lies in the fact that the latter only offers us a revelation of the human being within the temporal form and the former only the lasting element of the person's nature, the precipitation of their past in the substantial form of their features, so that, as it were, we see the succession of their life in simultaneity before us. (Simmel, 1997: 113-14)
}

Simmel argues that while the spoken and heard word contains objective meaning which could be transmitted in a different way, the look cannot be substituted and so weaves people together, creating a unity between them. Directly suspended in the event and its function, the look comprises a more direct and less differentiated connection than sound, focusing on what is alike in people rather than what distinguishes them from each other. In order to illustrate this point, Simmel (1997: 117) turns his attention to the students in an auditorium listening to a lecture who 'somehow feel themselves to be a unity' because they 'see each other during the communalizing process but cannot speak'. Similarly, both Simmel and Strindberg 
describe the sense of alienation caused by the form of life in the metropolis, based on seeing others without talking to them (Asendorf, 1984: 125).

Simmel (1997: 117) maintains that the 'division of labour' between the senses, in which the ear is associated with perception of the fleeting ('the wealth of divergent moods of individuals') and the eye, with the lasting, is tempered by the fact that people have a much greater ability to recall what has been heard than what has been seen. In contradiction, however, the reports of Simmel's lectures which form the source material for the present investigation tend to focus on the visual rather than the audible. ${ }^{9}$ Claiming that 'he thought visibly' (Gassen and Landmann, 1958: 147), that he was a person who 'philosophized with his whole body' (1958: 161), that 'he thought with his whole body' (1958: 163), that 'he presented the concepts in the flesh' (1958: 193), many of these impressions provide vivid descriptions of Simmel's use of his body as he spoke. In so doing, they provide an insight into the importance of kinesis in verbal communication which, according to Sample, provides 'a sensual, expressive background dimension' that exists concurrently with the semiotic dimension of language.

Many of the reports of Simmel's lectures mention that the intensity of his thought was expressed in his body, repeatedly emphasizing the manner in which he would raise his arm, point his fingers and twist his body as he spoke (for example, Gassen and Landmann, 1958: 229). And indeed, a sketch produced by one of Simmel's students during a lecture depicts Simmel in a similar position (see Figure 1). Other reports describe Simmel's 'strange appearance' in detail,

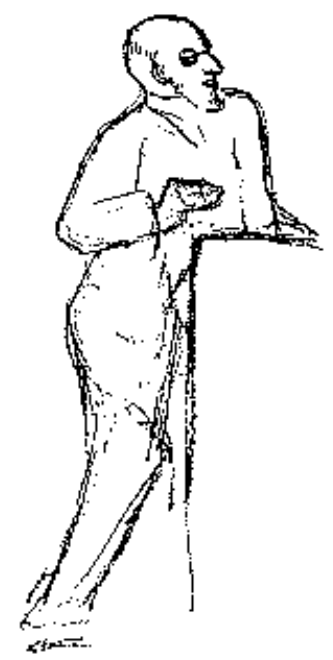

Figure 1 Simmel at the lecturn, 1906

Source: Böhringer and Gründer (1976). Reproduced by kind permission of the publishers. 
maintaining that Simmel's manner of lecturing was 'just as ugly and as fascinating as he himself was' (1958: 156). The continual repetition of adjectives such as 'ugly', 'gaunt', 'twisted' and 'awkward' suggests that reactions to Simmel's physical appearance were as ambivalent as those to his voice. Just as his voice appears both to have attracted and repulsed sections of his audience, so his 'grotesque' body image fascinated his students, perhaps because, in Bakhtinian fashion, it underlined the 'counter-cultural' experience and content of many of Simmel's lectures. Moreover, while the subjective perceptions of Simmel's voice and physical appearance are ambivalent, the reports of his lectures are almost unanimous in emphasizing the ubiquity and effectiveness of his use of vocalization and kinesis in communicating the objective content of his lectures, and simultaneously, giving the impression that each lecture was being created for the first time in the presence of the audience.

Highlighting the theme of embodiment, many reports of Simmel's lectures utilize metaphors of birth to describe the experience of witnessing Simmel's thought-processes. For example, Margarete Susman maintains that 'Simmel's lectures were extraordinary: he spoke in a lively fashion, completely without notes, as if every single thought was being born just at the moment in which it was being articulated' (Gassen and Landmann, 1958: 279), while Georg Hermann remembers that 'you had the feeling that you were witnessing the birth of his thoughts when he spoke' (1958: 163). These reports centre on the productivity of the speaker and the role that physiognomic expression played in delivering the illusion of creativity in the course of Simmel's lectures. In so doing, they confirm Ludwig's (1912: 1589-90) argument that the performance of the lecturer is closely connected to the performance of the acrobat (Körperkünstler), the star of variety theatre, since in both cases, the audience perceives productivity in the present. According to the logic of Ludwig's argument, the popularity of the acrobat, and concomitantly, of the speaker, is an indicator of the reawakening of interest in the body at the turn of the century resulting from the search for new forms of perception.

During the course of his lectures, Simmel appeared to speak and act spontaneously and yet, as Paul Fechter (Gassen and Landmann, 1958:161) reveals, this was often an elaborate act. He recalls having attended a public lecture given by Simmel in Berlin around 1912 on the problem of style in the Arts and Crafts Movement. During the lecture, Fechter took notes which he wrote up into a newspaper article the following day. However, before he could submit the article for publication, an older colleague at the Vossische Zeitung recognized the title of Fechter's article and produced a report of a lecture which Simmel had held in 1909 under the same title. On comparison, the articles demonstrated such a striking similarity that Fechter concluded: 
... without using a text, Simmel had delivered the same lecture as before; he had mastered the sound of the words, and using the sound of the words, he had conjured up for his audience the same performance of the process of thinking which had accompanied his first lecture, perhaps even with the same gestures. (Gassen and Landmann, 1958: 161)

According to Goffman (1981), one of the central distinctions between the written text and the lecture as the embodiment of text is grounded in the uniqueness of the lecture as performance. Similarly, Loenhoff (1997) focuses on the methodological difficulties posed by the performative aspect of the communicative event. Although in Simmel's case, articles such as Fechter's demonstrate the illusory nature of spontaneity, the sheer number of reports of Simmel's lectures which focus on this aspect of his performance document the success of the illusion. And indeed, the illusion of spontaneity is an important aspect of the ritual character of performance in this form of the dissemination of knowledge which in the Durkheimian ... sense [affords] supplicants preferential contact with an entity held to be of value' and is grounded in the sense of uniqueness of the occasion (Goffman, 1981: 187). Moreover, at the turn of the century, a heightened sense of 'preferential contact' with the speaker characterized the 'new' lecture form, or 'Conférence' (Bahr, 1897). This new form of communication, which Bahr claimed to have imported to the German-speaking world from Paris, was 'neither a sermon, nor doctrine, nor entertaining conversation and yet comprises a little of all three. You behave as though you were at the fireside and yet also as though at the lectern' (Bahr, 1897: 1). In a similar fashion, Max Dessoir (1902) described modern communicative events in terms of a blurring of the boundary between the speech and the conversation, arguing that while the dominant style of speaking in classical antiquity and the Renaissance was the monological speech, modernity demanded dialogical communication.

However, while the lecture form would seem to grant the audience 'preferential contact' with the speaker, a close analysis of the role of facial expression, the final category in this examination of 'communicative bodies', subverts this claim. Since both vocalization and kinesis figure continually in descriptions of Simmel as lecturer, it is all the more striking that scant attention is paid to Simmel's use of facial expression. Simmel's (1995: 36-42) study of the 'Aesthetic Meaning of the Face', in which he concludes that the face represents a dialectic of concealing and revealing, suggests a possible reason for this apparent oversight. In the context of the lecture, while vocalization and kinesis are both grounded in the feeling of closeness that is created when an idea is voiced by its originator (Gadamer, 1993), the dialectic of concealing and revealing means that facial expression is more complex; distance is added to the feeling of closeness. While Simmel (1997: 115) argues that the reciprocity of the look binds people together, this is missing from 
his lectures in which, although he was gazed upon, he did not reciprocate the look, thereby distancing himself from his audience. And indeed, Susman's comment that she saw Simmel's eyes for the first time at the end of his lecture course, in a one-to-one situation, illustrates the distance that Simmel created in the lecture situation (Gassen and Landmann, 1958: 279). Moreover, Hermann suggests that although Simmel's lectures were based on dialogue, it was a dialogue with himself rather than with his audience (1958: 163), providing further evidence that the experience of Simmel's lectures was based on the perception of distance as well as proximity.

In a letter to Rickert, dated 15 August 1898, in which he complains that the brightly coloured clothing of the many women who attended his lectures distracted him, Simmel confirms that he preferred to distance himself from his students while lecturing: 'Since I don't really speak to the audience, but to myself, I like it best when the auditorium is as colourless and indifferent as possible' (Gassen and Landmann, 1958: 96). As well as providing an insight into Simmel's perception of his lecturing style, this letter draws attention to his interest in the realm of fashion. In his analysis of fashion in modernity, found in its most extended form in 'The Philosophy of Fashion', Simmel uses the example of Parisian fashion to illustrate the 'tension and reconciliation of its [fashion's] dualistic elements', since 'the individual appearance never clashes with the general style, but always stands out from it' (Simmel, 1997: 191). In other words, he focuses on the way in which fashion contains impulses towards homogenization and individuation, simultaneously displaying and disguising difference. Thus, his analysis of fashion underlines the central argument in the 'Aesthetic Meaning of the Face', which states that the face signifies a dialectic of concealing and revealing.

In the context of the lecture, the dialectic of concealing and revealing plays on the interaction between proximity and distance. As Loenhoff (1997) argues, an adequate analysis of the complex communicative event must also investigate the nature of the restrictions imposed by the body on the event. Despite the introduction of the 'Conférence' and a corresponding theoretical emphasis on the importance of dialogical communication in turn-of-the-century calls for a new form of public speaking which emphasized the sense of closeness to the audience created by an immediate interaction between tone and meaning, in the case of Simmel's lectures, the restrictions stem from the creation of distance between the speaker and the audience. This creation of distance did not only function at the level of the obvious physical distance between the speaker standing at the lectern and speaking, and the audience sitting and listening, but also at a more subtle level, whereby Simmel avoided reciprocating the gaze of his audience. In other words, 
just as Simmel's urban sociology involved him maintaining a certain distance between himself and the urban masses, allowing Simmel to retreat to the safety of the salon (Frisby, 1985), so in disseminating his ideas through the lecture form, Simmel distanced himself from his audience in an attempt to protect the Self, while playing on an illusion of closeness.

In terms of Simmel's sociology, this dialectic of distance and closeness upon which the lecture form is predicated, can be understood in terms of the gap between subjective and objective culture that characterizes modernity. While the lecture form facilitated the circulation of individuals in modernity, the body of the lecturer appears as 'the commodity image of the human body' - the body image which corresponds to the bourgeois world-view (Ferguson, 1997: 6). It is, first and foremost, the body which is perceived and consumed as spectacle by the audience. However, in the terms of this world-view, which conceives the body as a barrier between objective and subjective culture, the audience has 'preferential contact' only with the commodity image and not with the Self which the lecturer conceals. Just as fashion functions to aid impulses towards both individuation and homogenization, so the lecture form provides a stage for both self-representation and protection of the Self. Moreover, the lecture is a communicative event in which the 'communicative body' not only functions to reveal ideas which cannot be expressed through verbal language, but also to conceal their origin. In other words, the lecture form, as practised and theorized by Simmel, is based on a tension between subjectivity as spectacular and subjectivity as performative. Simmel's performances continually subverted the close relationship between the text and its author/embodier, forcing his audience, in a manner similar to the Brechtian Verfremdungseffekt, to think beyond the apparent unity between text and author represented by the embodiment of text, and therefore, to recognize the ever-increasing cleft between subjectivity and objectivity.

\section{Notes}

This article is a revised version of a paper first presented at the 1998 BSA Conference, Making Sense of the Body. I would like to thank the Leverhulme Trust for a Study Abroad Scholarship that allowed me to carry out the research for this article.

1. A comprehensive list of Simmel's university lectures can be found in Gassen and Landmann (1958: 346-49); I have translated all the quotations from this volume for this article.

2. This translation appears in Frisby (1992: 102).

3. A report of this lecture can be found in the Berliner Tagblatt of 17 March 1916. True to Simmel's style, this lecture probably grew out of a series of lectures which Simmel held in Eastern Europe and Russia in 1912 (reported in the St Petersburger Monatsblatt Nr. 463, the Ostsee Zeitung of 28 September 1912, and the Potsdamer Tageszeitung of 5 October 1912). 
4. Therefore, this study implicitly takes issue with Turner's (1996: 26) claim that 'classical sociology neglected the issue of the body in social action'.

5. The sheer number of lectures advertised and reported in the daily newspapers from the turn of the century provides ample evidence for the popularity of the lecture as a means of communication before the days of electronic mass communication. This is underlined by an on-going theoretical discussion in journals such as the Nene Rundschan, Die Schaubühne and others, as well as in booklength studies on speech-making and rhetoric.

6. In 'The Science of Correspondences', Benjamin (1977: 209) locates the lost mimetic capacity in the sounds of a sentence, but in the same article, articulates the concept of non-sensuous correspondences (1977: 207). However, in 'On Language in General and on Human Language', Benjamin (1977: 140) argues that language covers all expressions of human mental life, suggesting that his concept of language is not reducible to what Sample has labelled 'conventional language'. Similarly, in 'Problems of Socio-Linguistics', he argues that dance overcomes the threshold to 'linguistic physiognomy' (Benjamin, 1972: 478).

7. Kroner's description, bringing Simmel's voice to life, neatly illustrates Sample's (1996: 121) argument that in order to write adequately on art or aesthetics, aesthetic language which tunes into physiognomic perceptions and articulates physiognomic perceptions, thereby enriching the articulatory resources of conventional language is needed. Moreover, the combination of the ideal and the sensuous highlighted in this passage suggests that Simmel's lectures were a site in which 'aesthetic ideas' were at play.

8. This view contradicts Adorno's (1991) distinction between the lecture and the essay contained in 'The Essay as Form'. In his text, Adorno contrasts the essay with other carriers of discourse, including the lecture, arguing that the scientific world-view and its corresponding use of discursive logic has effected a change in the nature of the lecture. This has now lost its grounding in dialogical communication and become merely a means of imparting knowledge (i.e. monological communication). Adorno then concludes that the essay is the only form which conserves traces of communicative language through its autonomy of representation.

9. Thus it is necessary to reflect on the nature of memory, considering to what extent these reports of Simmel's lecturing style comprise a canon which has been developed around Simmel. Some of the later contributions in Buch des Dankes acknowledge this problem. For example, see Gassen and Landmann (1958: 300).

\section{References}

Adorno, T. (1991) Notes to Literature, vol. 1, ed. Rolf Tiedemann, trans. Shierry Weber Nicholson. New York: Columbia University Press.

Asendorf, C. (1984) Batterien der Lebenskraft. Gießen: Anabas.

Bab, J. (1906) 'Die Körperkunst', Die Schaubühne 2(52): 631-3.

Bahr, H. (1897) Renaissance. Neue Studien zur Kritik der Moderne. Berlin: Fischer.

Barlösius, E. (1997) Naturgemäße Lebensfübrung: zur Geschichte der Lebensreform um die Jabrbundertwende. Frankfurt a.M., New York: Campus Verlag.

Benjamin, W. (1972) Gesammelte Schriften, vol. 3, ed. H. Tiedemann-Bartels. Frankfurt a.M.: Suhrkamp.

Benjamin, W. (1977) Gesammelte Schriften, vol. 2, ed. R. Tiedemann and H. Schweppenhäuser. Frankfurt a.M.: Suhrkamp.

Benjamin, W. (1982) Gesammelte Schriften, vol. 5, ed. R. Tiedemann. Frankfurt a.M.: Suhrkamp.

Benjamin, W. (1992) Illuminations, trans. H. Zohn. London: Fontana.

Benthall, J. and T. Polhemus (eds) (1975) The Body as a Medium of Expression. London: Allen Lane.

Blondel, E. (1991) Nietzsche: The Body and Culture. London: Athlone Press. 
Böhringer, H. and K. Gründer (eds) (1976) Asthetik und Soziologie in die Jabrbundertwente: Georg Simmel. Frankfurt a.M.: Vittorio Klostermann.

Bühler, K. (1990) Theory of Language: The Representational Function of Language. Amsterdam: John Benjamins.

Cicero, M.T. (1942) De Oratore, trans. E.W. Sutton and H. Rackham. London: Heinemann.

Dessoir, M. (1902) 'Rede und Gespräche', Die Zeit, 29 March: 198-9.

Douglas, M. (1970) Natural Symbols: Explorations in Cosmology. London: Barrie and Rockliff, Cresset Press.

Ferguson, H. (1997) 'Me and My Shadows: On the Accumulation of Body-Images in Western Society Part Two - The Corporeal Forms of Modernity', Body \& Society 3(4): 1-31.

Frank, A. (1991) 'For a Sociology of the Body: An Analytical Review', pp. 36-94 in M. Featherstone, M. Hepworth and B. Turner (eds) The Body: Social Process and Cultural Theory. London: Sage.

Frisby, D. (1985) Fragments of Modernity. Cambridge: Polity.

Frisby, D. (1992) Sociological Impressionism. London: Routledge.

Gadamer, H.G (1993) Gesammelte Werke, vol. IX. Tübingen: Mohr.

Gassen, K. and M. Landmann (eds) (1958) Buch des Dankes an Georg Simmel. Berlin: Duncker and Humblot.

Geisler, E. (1914) Rhetorik, 2 vols. Leipzig/Berlin: B.G. Teubner.

Giddens, A. (1991) Modernity and Self-Identity: Self and Society in the Late Modern Age. Cambridge: Polity.

Goffman, E. (1969) The Presentation of Self in Everyday Life. London: Allen Lane.

Goffman, E. (1981) Forms of Talk. Oxford: Blackwell.

Kalverkämper, H. (1994) 'Die Rhetorik des Körpers: Nonverbale Kommunikation in Schlaglichtern', pp. 131-69 in J. Dyck, W. Jens and G. Ueding (eds) Körper und Sprache, vol. 13, Rhetorik. Ein Internationales Jabrbuch. Tübingen: Niemeyer.

Loenhoff, J. (1997) 'The Negation of the Body - A Problem of Communication Theory', Body $\mathcal{E}$ Society, 3(2): 67-82.

Ludwig, E. (1912) 'Genialität des Körpers', Nene Rundschan 23(2): 1589-92.

Luhmann, N. (1992) Die Wissenschaft der Gesellschaft. Frankfurt a.M.: Suhrkamp.

Mach, E. (1987) Die Analyse der Empfindungen. Darmstadt: Wissenschaftliche Bibliothek.

Mattenklott, G. (1983) 'Der mythische Leib: Physiognomisches Denken bei Nietzsche, Simmel, und Kassner', pp. 138-56 in K.H. Bohrer (ed.) Mythos und Moderne. Begriff und Bild einer Rekonstruktion. Frankfurt a.M.: Suhrkamp.

Moynahan, G. (1996) 'The Problems of Physiognomy and the Development of Cultural Theory in Georg Simmel and Ernst Cassirer', Simmel Newsletter 6(1): 44-56.

Nedelmann, B. (1983) 'Georg Simmel - Emotion und Wechselwirkung in intimen Gruppen', Kölner Zeitschrift für Soziologie und Socialpsychologie, Sonderheft 25: 174-209.

Nietzsche, F. (1969) Thus Spoke Zarathustra. Harmondsworth: Penguin.

Probst, H. (1916) Deutsche Redelehre. Berlin/Leipzig: Göschen'sche Verlagsbuchhandlung.

Quintilian, M. (1920-22) Institutio Oratoria, trans. H.E. Butler. London: Heinemann.

Sample, C. (1996) 'Living Words. Physiognomy and Aesthetic Language', pp. 113-26 in M. O’Donovan-Anderson (ed.) The Incorporated Self. Lanham, MD: Rowman and Littlefield.

Simmel, G. (1995) Aufsätze und Abbandlungen 1901-1908, I, vol. 7, Gesamtausgabe, R. Kramme (ed.). Frankfurt a.M.: Suhrkamp.

Simmel, G. (1997) Simmel on Culture, ed. D. Frisby and M. Featherstone. London: Sage.

Simmel, H. (1976) 'Auszüge aus den Lebenserinnerugen', pp. 247-68 in H. Böhringer and K. Gründer (eds) Ästhetik und Soziologie um die Jabrbundertwende: Georg Simmel. Frankfurt a.M.: Vittorio Klostermann.

Shilling, C. (1993) The Body and Social Theory. London: Sage.

Turner, B. (1996) The Body and Society, 2nd edn. London: Sage. 
16 - Body and Society Vol. 5 No. 4

Weigel, S. (ed.) (1992) Leib- und Bildraum. Lektüren nach Benjamin. Cologne, Weimar, Vienna: Böhlau.

Wunderlich, H. (1898) Die Kunst der Rede in ibren Hauptzügen an den Reden Bismarcks. Leipzig: S. Hirzel.

Janet Stewart is a lecturer in German at Aberdeen University. She completed her PhD, 'Excavating Adolf Loos's Cultural Criticism' in 1998 and is currently investigating public lectures held in Vienna and Berlin (1890-1938). 